\title{
Analysis of Microstructure Changes for AISi7Mg0.3 Alloy Caused by Modification
}

\author{
Iryna Hren, Jaroslava Svobodova, Štefan Michna
}

Faculty of Mechanical Engineering, J. E. Purkyne University in Usti nad Labem. Pasteurova 3334/7, 40001 Usti nad Labem.Czech Republic.E-mail: iryna.hren@ujep.cz, jaroslava.svobodova@ujep.cz, Stefan.michna@ujep.cz

\begin{abstract}
The aim of this experiment was to investigate the influence of the $\mathrm{Sr}$ modifier in the Al-Si eutectic alloy on the structure change and its mechanical properties. For this reason, an Al-Si7Mg0.3 hypoeutectic silumin alloy was modified with the aim of improving the mechanical properties of the material, mainly by increasing the ductility and strength. The subject of investigation was analysis of morphology of excreted eutectic silicon. In order to investigate the surface, metallographic cross-sectional specimens were prepared using light and electron microscopy. A static tensile test was performed for detailed examination. It has been found that the addition of the AISr10 modifier and, over the time of modification of 1 to 2 hours, has increased the mechanical properties, in particular the ductility.
\end{abstract}

Keywords: $\mathrm{AlSi} 7 \mathrm{Mg} 0.3$, modification, strontium, microstructure.

\section{Introduction}

The gravity casting process is one of the precision casting processes in which the mold is filled with melt due to the gravity of the molten metal $[1,2]$. The casting is carried out by means of a ladle into a sand or preheated metal mold. This casting method is used for casting light metal alloys. A wide variety of weight categories can be produced. Gravity casting technology is mainly used for casting light metal alloys in the automotive industry, typical castings being wheel discs, cylinder heads and brake system components [3,4].

The AlSi7Mg0,3 hypoeutectic silumin alloy prepared for this research is modified by $\mathrm{Sr}$ and was developed for the automotive industry with the aim of refining the structure of the starting alloy and achieving higher mechanical properties (ductility and strength) and improving technological properties (castability and machinability).

In his work, Vergnano studied gravity casting technology for aluminum alloys [5]. Modeling of casting processes, including design of heating cycle simulation was verified by experiment. As a result of the research, control of the heating cycles and temperature parameters is very important to improve process accuracy. Bolondo [6] focused on comparing LPSD technology and gravity casting in the manufacture of safety boxes for chemical and marine equipment. The fact is that the use of this casting method makes it possible to obtain castings with very good strength and good metallurgical quality. For this reason, many advantages have been mentioned in the work, both metallurgically and economically. Malhotra [7] dealt with various types of defects in the casting of aluminum alloys using gravity casting technology. Shrinkage, porosity and gas leakage have a negative effect on the integrity of the material. In his work he showed that optimizing process parameter values can minimize the defect range and greatly influence the casting process. Sofyan and Falah [8] investigated the effect of modifiers on the microstructure and mechanical properties of $\mathrm{Al}-\mathrm{Si}$ alloys. In their work, they showed that strontium modification improves the impact toughness and ductility of the alloy. Timelli [9] studied the effect of strontium addition on microstructure and defects in AlSi7Mg0.3 alloy castings. He found that a higher $\mathrm{Sr}$ content will provide castings with a lower porosity. In his work, Cais [10] investigated the modification of $\mathrm{AlSi} 7 \mathrm{Mg} 0.3$ hypoeutectic silumin by antimony, and recommended an optimal amount of $0.15 \mathrm{wt} \%$ antimony, which significantly increases the tensile strength on average up to $230 \mathrm{MPa}$ compared to $190 \mathrm{MPa}$ without the use of antimony.

Gravity casting is a method where a very important aspect is to obtain castings of the highest quality with the lowest number of defects while maintaining high mechanical properties. The literature does not provide data on the diffusion coefficients $\mathrm{Sr}$ in real aluminum melt, which would allow the calculation of the required residence time at the temperature for complete dissolution of even the largest strontium particles. For this reason, a unique and extensive research and analysis of the $\mathrm{AlSi} 7 \mathrm{Mg} 0.3$ alloy has been carried out and the purpose of this study was to find the optimal time during which the modification process is still in progress. The efficiency of the modification can be maintained and further improved only with a detailed understanding of all stages of the process factors, and the prediction of changes in the microstructure can prevent premature end-of-life of the component.

\section{Experiment}

For the experiment, 4 samples were produced from AlSi7Mg0.3 hypoeutectic silumin alloy with the following chemical composition in weight percent of $6.9 \% \mathrm{Si}$, $0.18 \% \mathrm{Fe}, 0.047 \% \mathrm{Cu}, 0.0023 \% \mathrm{Mn}, 0.32 \% \mathrm{Mg}, 0.12 \%$ $\mathrm{Ti}, \mathrm{Al}-\mathrm{residue}$. This alloy has very good machinability, thermal conductivity and achieves tensile strength up to $250 \mathrm{MPa}$. The disadvantage is the presence of iron in the material, which impairs its mechanical properties and corrosion resistance. The resulting castings had the shape of a cylinder with parameters: length $-210 \mathrm{~mm}$ and diameter of about $19 \mathrm{~mm}$ and became the basis for the subsequent microstructure analysis.

The microstructure of the sample is shown in Fig. 1, which is a typical hypoeutectic silumin. The structure consists of $\alpha$ dendritic cells and a eutectic consisting of $\alpha$ 
- solid solution and silicon in the form of coarse hexagonal plates, which appear as sharp - angled irregular needles of different size in the metallographic cut.

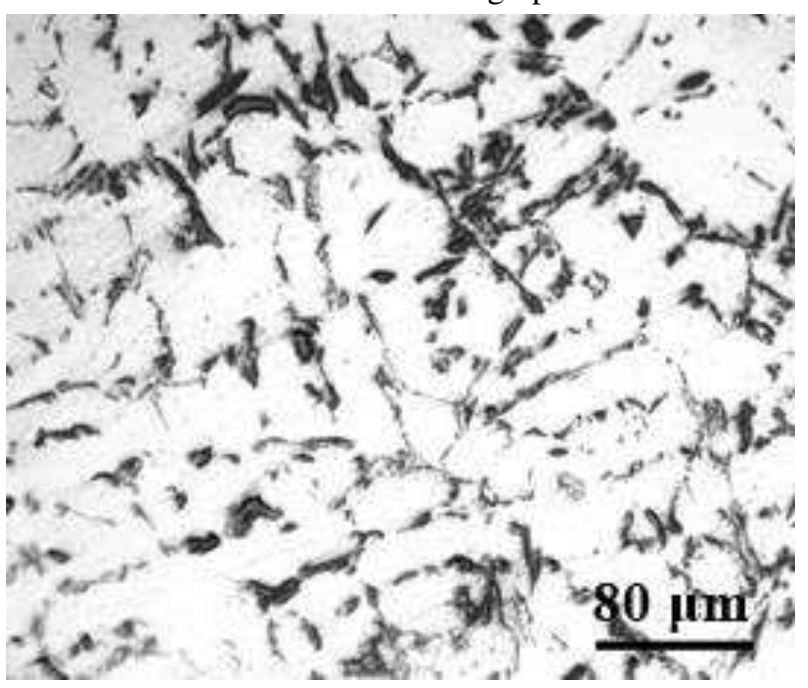

Fig. 1 Experimental representation of AlSi7MgO.3 alloy microstructure

In this work, AlSi7Mg0.3 alloy was prepared from purchased and already alloyed rolls according to the required chemical composition. The buns were melted at $720 \pm 5^{\circ} \mathrm{C}$ in an electric furnace. The weight of the charge was about $2000 \mathrm{~g}$. After melting the charge, the alloy was treated with refining salt. After treatment, the alloy was modified by introducing the AlSr10 modifier in the form of a wire with mechanical stirring for 30 seconds. The molten metal was poured into the mold after 30 minutes, 1 hour and 2 hours after strontium addition, to verify the modification process throughout the experiment.

\section{Results and discussion}

\subsection{Experimental methods}

The sample surface was cleaned in an ultrasonic cleaner and observed using a VEGA3 Electron Scanning Microscope (SEM) from Tescan. This device was equipped with an energy-dispersive X-ray detector (EDS), which allowed the study of the chemical composition of structural components. For the analysis of surface and subsurface microstructural changes, metallographic sections of the cast cross-section (perpendicular to the casting direction) were prepared. These preparations were prepared by conventional techniques - wet grinding and polishing with diamond emulsions. All samples were prepared manually. The final mechanicalchemical polishing was performed using a suspension of OPS from Struers. After etching with phosphoric acid, the structure of the material was observed and documented by electron and light microscopy on a LEXT OLS 3100 confocal laser microscope from Olympus.

\subsection{Microscopic evaluation of structure and quality of modification}

Microstructure of the casting with the addition of strontium at a concentration of $0.04 \%$ wt. is shown in Fig. 2 and 3 . As shown in the figure, the addition of strontium to the alloy caused a change in the morphology of the silicon excreted particles. Thus, compared to the resulting unmodified alloy, there is a trend of eutectic deposition of silicon in the form of significantly smaller particles. As a result of the addition of strontium to the melt, the silicon particles are rounded and the silicon is deposited in the form of rounded globulitic particles.

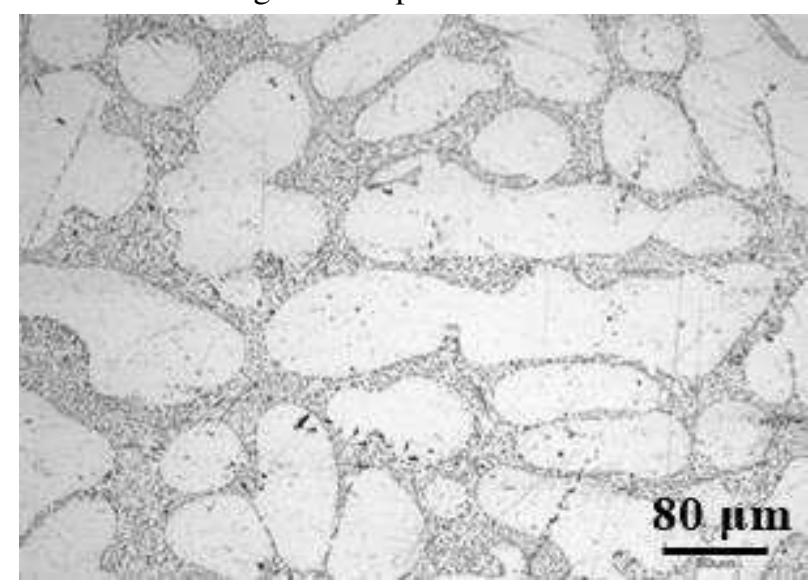

Fig. 2 Microstructure of the ally with 0.04 wt \% Sr (30 min)

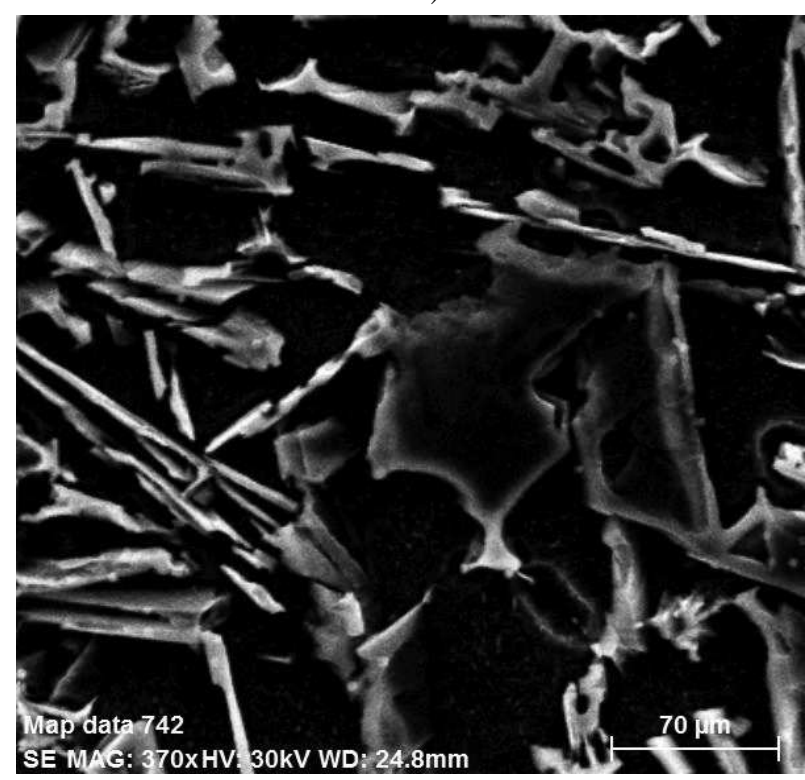

Fig. 3 Microstructure of the alloy with the $0.04 \mathrm{wt} \% \mathrm{Sr}$ after 30 min of modification (SEM)

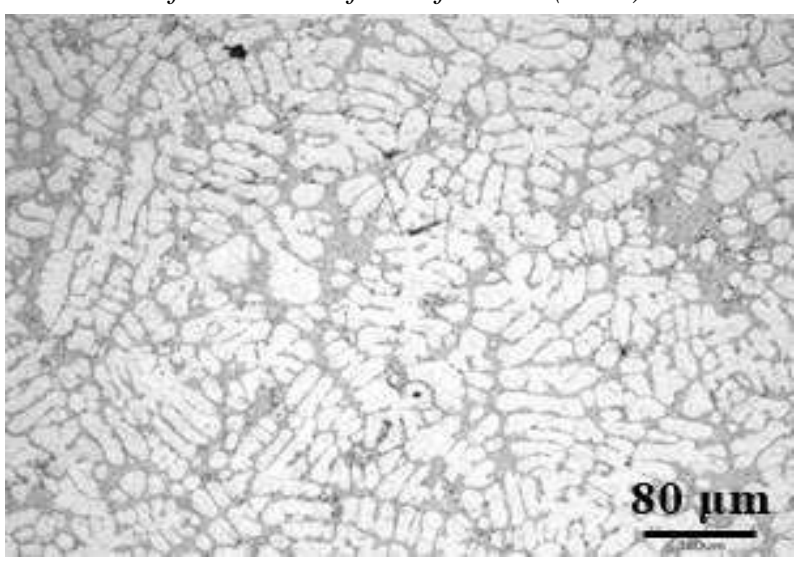

Fig. 4 Microstructure of the alloy with the 0.04 wt \% Sr $(1 \mathrm{~h})$ 


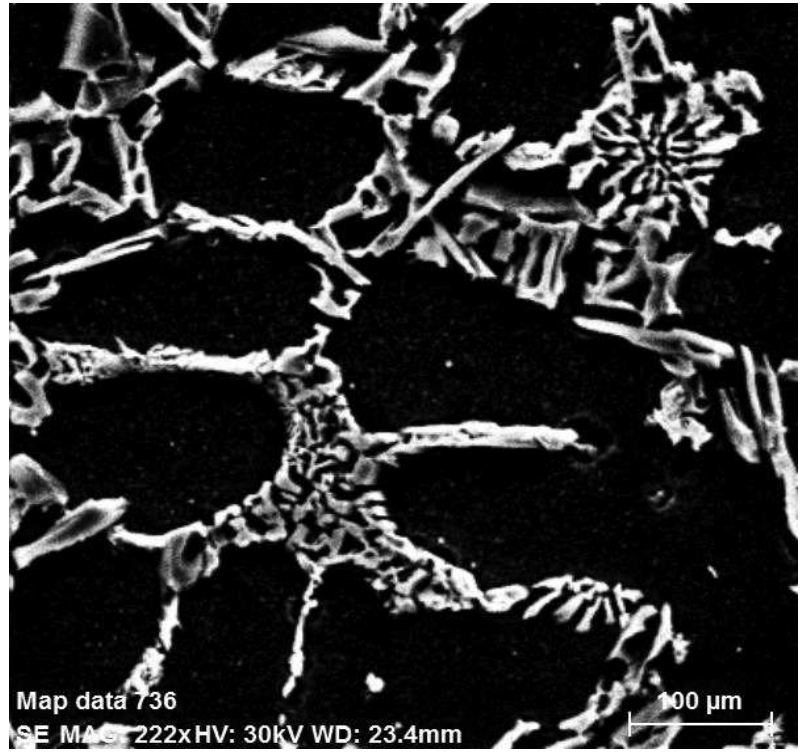

Fig. 5 Microstructure of the alloy with the $0.04 \mathrm{wt} \% \mathrm{Sr}$ after 1 hour of modification (SEM)

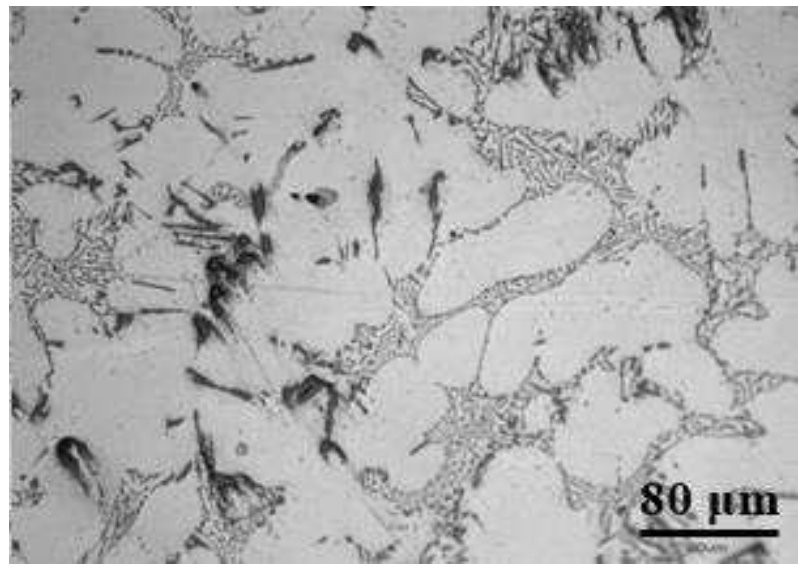

Fig. 6 Microstructure of the alloy with the $0.04 \mathrm{wt} \% \mathrm{Sr}$ (2h)

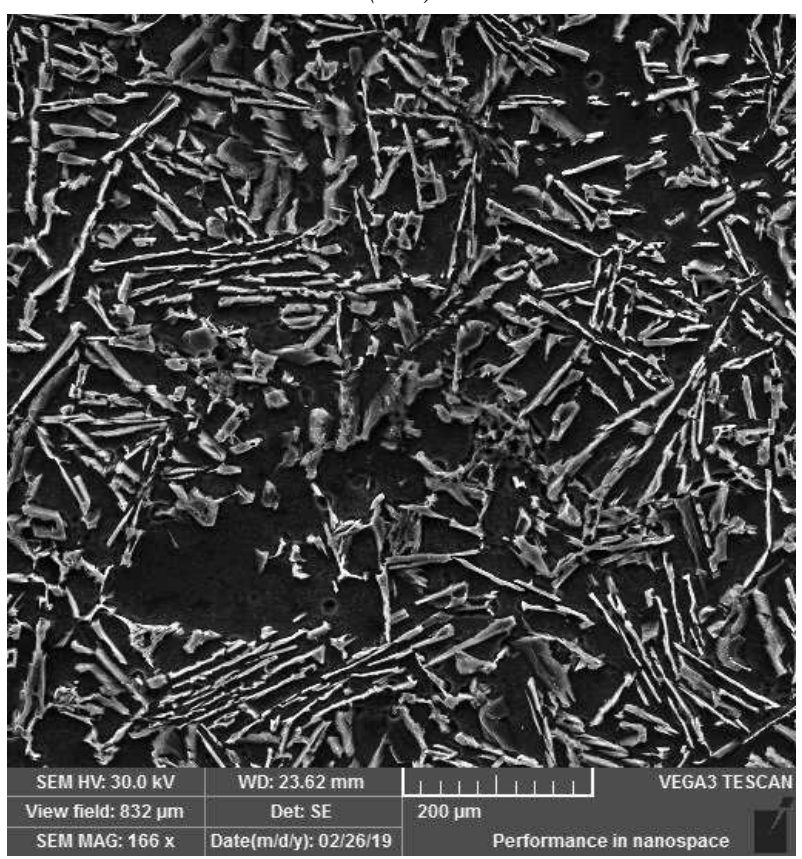

Fig. 7 Microstructure of the alloy with the $0.04 \mathrm{wt} \% \mathrm{Sr}$ after 2 hour of modification (SEM)
Significant change occurs in the sample cast one hour after the modification. The figure shows the trend of further refinement of eutectic silicon particles, which is eliminated in the microstructure of the sample in the form of small regular globulite particles up to fine rounded plates up to $20 \mu \mathrm{m}$ (Fig. 4,5).

As can be seen in Fig. 6 and 7, after the addition of strontium to the original material, the size of the eutectic silicon needles increases, resulting in widening of the plates of the eutectic phases. Several thin plates are also combined to form long needle-like Si particles. This indicates that the shape of the deposited eutectic silicon begins to change from rod-shaped to plate-like. This is probably due to the fact that the modifying effect of strontium is slowly beginning to disappear [4].

\subsection{Scanning electron microscopy and EDS analysis}

A Tescan VEGA3 electron microscope was used to examine the microstructure of an alloy sample by scanning electron microscopy. The chemical composition of the structural components secreted in the microstructure was determined using energy dispersive spectrometry (EDS) by means of a Bruker EDS analyser.

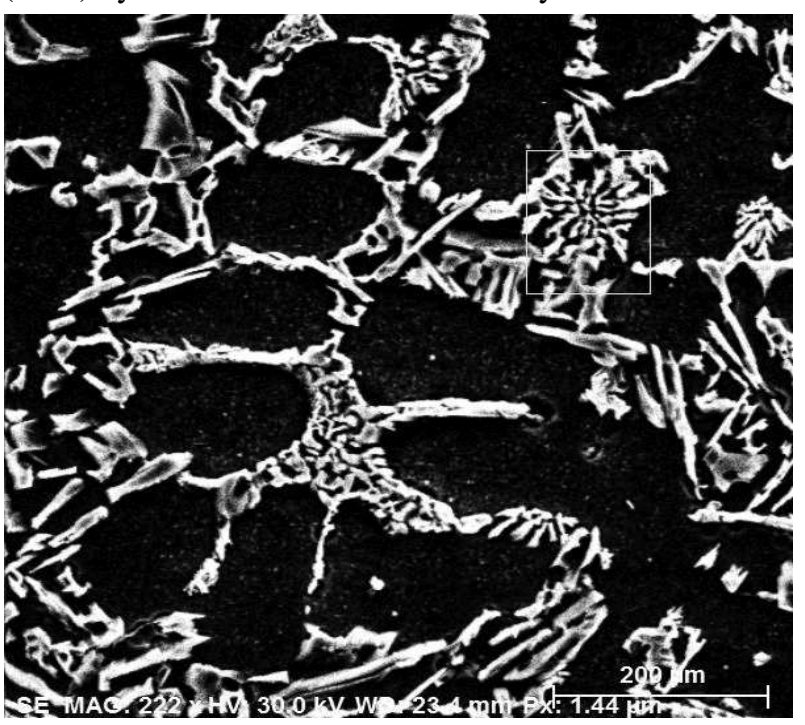

Fig. 8 Microstructure of the sample after 1 hour of modification

Tab. 1 Quantification of results of areal EDS analysis

\begin{tabular}{|c|c|c|c|c|c|}
\hline $\begin{array}{c}\text { Ele- } \\
\text { ment }\end{array}$ & Series & $\begin{array}{c}\text { unn. } \\
\text { C } \\
\text { [wt. } \\
\%]\end{array}$ & $\begin{array}{c}\text { norm. } \\
\text { C } \\
{[\text { wt. }} \\
\%]\end{array}$ & $\begin{array}{c}\text { Atom. } \\
\text { C } \\
\text { [at. \%] }\end{array}$ & $\begin{array}{c}(3 \\
\text { Sigma }) \\
\text { [wt. } \\
\%]\end{array}$ \\
\hline $\mathbf{A l}$ & $\begin{array}{c}\text { K-se- } \\
\text { ries }\end{array}$ & 47.06 & 54.98 & 57.70 & 7.39 \\
\hline $\mathbf{F e}$ & $\begin{array}{c}\text { K-se- } \\
\text { ries }\end{array}$ & 5.34 & 6.24 & 3.16 & 0.81 \\
\hline $\mathbf{S i}$ & $\begin{array}{c}\text { K-se- } \\
\text { ries }\end{array}$ & 31.5 & 36.81 & 37.1 & 4.77 \\
\hline $\mathbf{S r}$ & $\begin{array}{c}\text { K-se- } \\
\text { ries }\end{array}$ & 0.27 & 0.31 & 0.1 & 0.05 \\
\hline $\mathbf{M g}$ & $\begin{array}{c}\text { K-se- } \\
\text { ries }\end{array}$ & 1.42 & 1.66 & 1.93 & 0.48 \\
\hline Total: & & 85.59 & 100.00 & 100.00 & \\
\hline
\end{tabular}


In Fig. 8, the area where the presence of strontium has been identified is indicated by a rectangle. The quantification of the results from the indicated area shows that there is a strontium particle on the surface of the silicon particles and is shown in Tab. 1. The record of the performed EDS analysis is shown in Fig. 9.

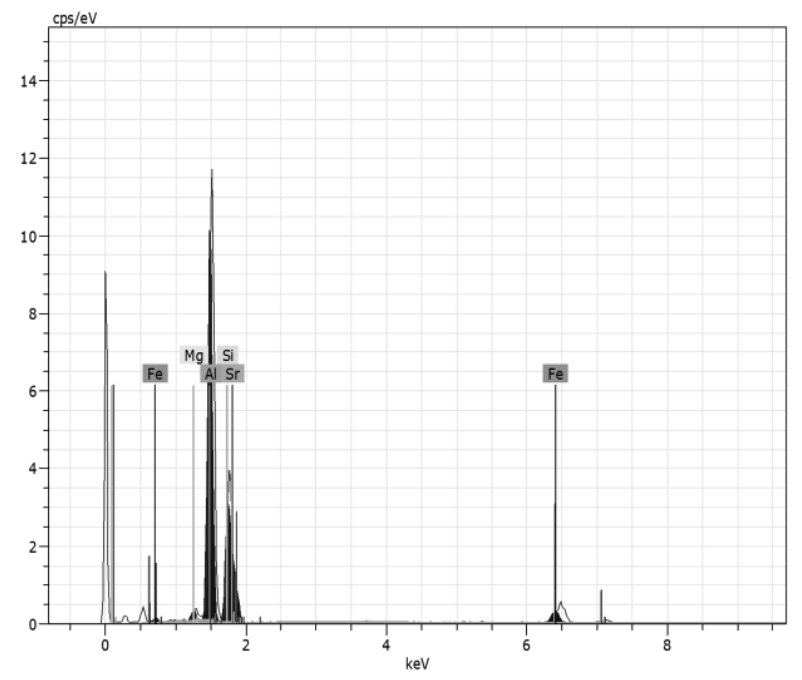

Fig. 9 Recording of EDS area analysis

After another modification period, strontium was captured in only two samples after 2 hours of modification.

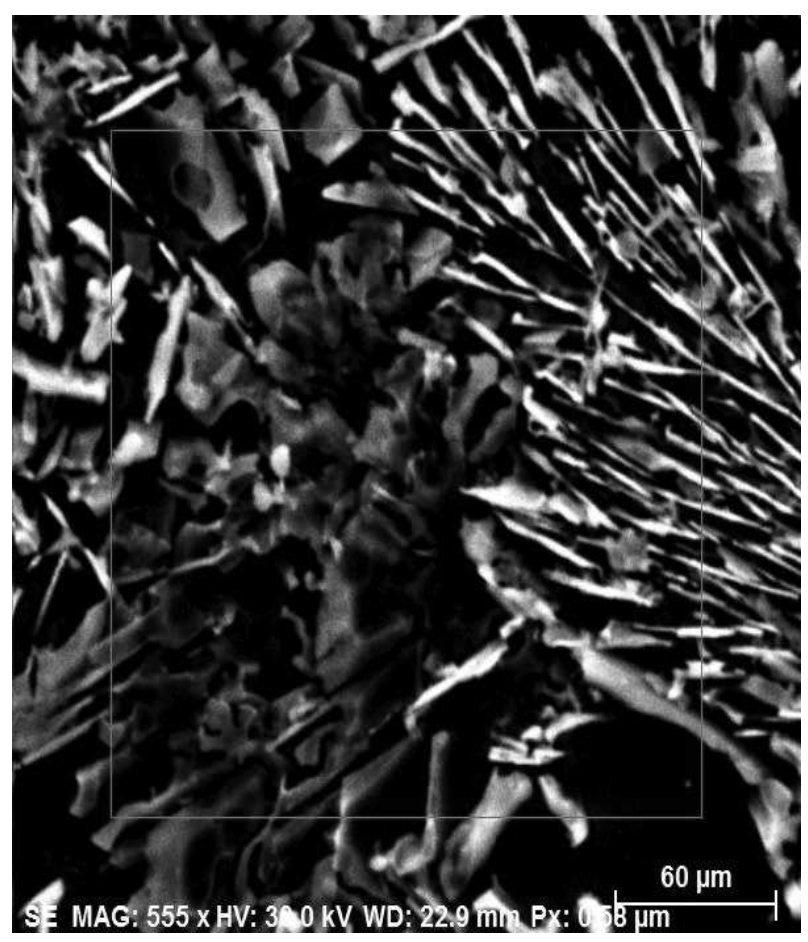

Fig. 10 Microstructure of the sample after 2 hours of modification

When investigating other samples, the EDS analysis also confirmed that the $\mathrm{AlSr}_{4}$ type intermetallic phases spread on the surface of silicon particles (Fig. 10), which is confirmed by the EDS surface analysis from the surface is indicated as Fig. 11. Quantification of EDS results is recorded in Tab. 2.

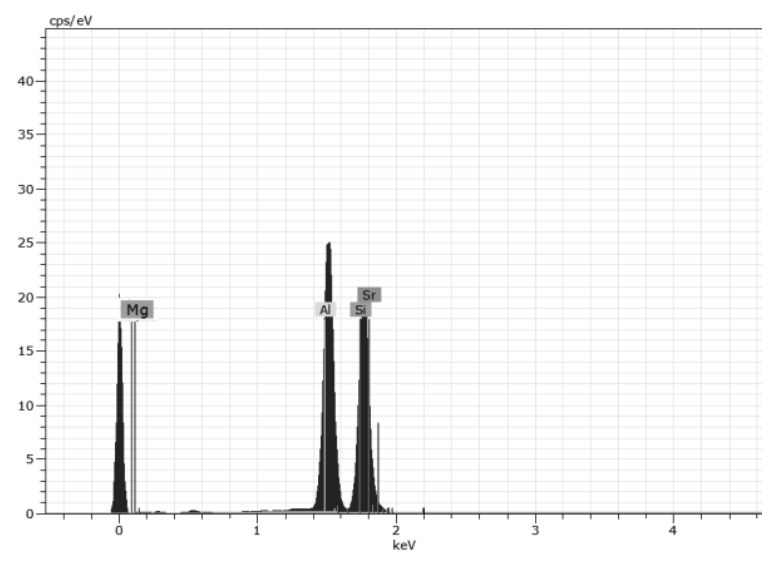

Fig. 11 Recording of EDS area analysis

Tab. 2 EDS analysis

\begin{tabular}{|c|c|c|c|c|c|}
\hline $\begin{array}{c}\text { Ele- } \\
\text { ment }\end{array}$ & $\begin{array}{c}\text { Se- } \\
\text { ries }\end{array}$ & $\begin{array}{c}\text { unn. C } \\
\text { [wt.\%] }\end{array}$ & $\begin{array}{c}\text { norm. } \\
\text { C } \\
\text { [wt.\%] }\end{array}$ & $\begin{array}{c}\text { Atom. } \\
\text { Cat.\%] }\end{array}$ & $\begin{array}{c}\mathbf{( 3} \\
\text { Sigma) } \\
\text { [wt.\%] }\end{array}$ \\
\hline $\mathbf{A l}$ & $\begin{array}{c}\text { K- } \\
\text { se- } \\
\text { ries }\end{array}$ & 65.48 & 63.02 & 63.95 & 10.67 \\
\hline $\mathbf{S i}$ & $\begin{array}{c}\text { K- } \\
\text { se- } \\
\text { ries }\end{array}$ & 37.23 & 35.83 & 34.93 & 6.66 \\
\hline $\mathbf{S r}$ & $\begin{array}{c}\mathrm{K}- \\
\text { se- } \\
\text { ries }\end{array}$ & 0.22 & 0.21 & 0.07 & 0.07 \\
\hline $\mathbf{M g}$ & $\begin{array}{c}\mathrm{K}- \\
\text { se- } \\
\text { ries }\end{array}$ & 0.97 & 0.94 & 1.05 & 0.52 \\
\hline Total: & & 103.9 & 100.00 & 100.00 & \\
\hline
\end{tabular}

\section{Conclusion}

Based on the experiment, 5 samples were cast from AlSi7Mg0,3 eutectic silumin, which were then examined in detail to study the effect of adding $0.04 \%$ AlSr 10 modifier on the structure of the material and the change in eutectic silicon morphology. Based on the analyzes, the following conclusions were reached:

- in the microstructure of AlSi7Ng0,3 in the unmodified state, silicon was eliminated in the form of hexagonal plates,

- adding 0.04 wt. \% Sr in the alloy causes a change in the morphology of eutectic silicon particles by refining up to $20 \mu \mathrm{m}$,

- as a result of modification of strontium, the particles of eutectic silicon are rounded and are eliminated in the form of smaller particles,

- for a comprehensive evaluation of the effect of the modifier, cast samples were taken within 30min, 1 to 2 hours after AlSr10 addition, and it was found that after 2 hours of modification several thin plates were formed to form long needle- 
like $\mathrm{Si}$ phases, that the strontium modifying effect begins to fade and $\mathrm{Si}$ plates become coarse.

- analysis of static tensile test shows that the mechanical properties, especially ductility, are maintained for a period of 1 to 2 hours.

\section{Acknowledgements}

This contribution came from support of project $S G$ 4820715 2014-48 01 at UJEP.

\section{References}

[1] BOLIBRUCHOVÁ, D., MATEJKA, M.. (2018). Analysis of Microstructure Changes for AlSi9Cu3 Alloy Caused by Remelting. Manufacturing Technology, Vol. 18, No. 6, pp. 883-888.

[2] MICHNA, Š. a kol. (2005). Encyklopedie hliníku, 1. Vydání, Prešov, SR: Adin s. r. o.

[3] BOlibRUChOVÁ, D., TILlovÁ, E. (2005). Zlievarenské zliatiny Al-Si. Žilina: EDIS - vydavatel'stvo ŽU.

[4] TILlOVA, E., CHALUPOVA, M., HURTALOVA, L., DURINIKOVA, E. (2011). Quality Control of Microstructure in Recycled AlSi Cast Alloys. Manufacturing Technology, Vol. 11, No. 11, pp. 70-76.

[5] VERGNANO A., BRAMBILLA E., BONFIGLIOLI G. (2019). Efficiency and Relia- bility of Gravity Die Casting Models for Simulation Based Design. Advances on Mechanics, Design Engineering and Manufacturing II, Vol.1, pp. 3-12.

[6] Bonollo, F., Urban, J., Bonatto, B., \& Botter, M. (2005). Gravity and low pressure die casting of aluminium alloys: a technical and economical benchmark. La metallurgia italiana, Vol 6, pp. 2332.

[7] MALHOTRA, V.; KUMAR, Y. (2016). Study of Process Parameters of Gravity Die Casting Defects. Int. J. Mech. Eng. Technol, Vol. 7, pp. 208211.

[8] SOFYAN, B. T., KHARISTAL, D. J., TRIJATI, L., PURBA, K., \& SUSANTO, R. E. (2010). Grain refinement of AA333 aluminium cast alloy by Al-Ti granulated flux. Materials \& Design, Vol. 31, pp. 36-S43.

[9] TIMELLI, G., CALIARI, D., \& RAKHMONOV, J. (2016). Influence of process parameters and $\mathrm{Sr}$ addition on the microstructure and casting defects of LPDC A356 alloy for engine blocks. Journal of materials science \& technology, Vol. 32, No. 6, pp. 515-523.

[10] CAIS, J., SVOBODOVA, J., STANCEKOVA, D. (2017). Modification of the AlSi7Mg0,3 Alloy Using Antimony. Manufacturing Technology, Vol. 13, No. 5, pp. 685-690. 